\title{
Pozbawienie uprawnień wynikających z decyzji administracyjnej a realizacja zasady efektywności działania administracji
}

\begin{abstract}
Organ administracji publicznej, stosując określone formy działania, winien kierować się tym, że powinny być one najbardziej efektywne, najmniej uciążliwe dla obywatela, odpowiadać poczuciu prawnemu społeczeństwa o celowości lub niezbędności ich stosowania i ściśle mieścić się $\mathrm{w}$ ramach przewidzianych przez prawo.
\end{abstract}

J. Szreniawski, Prawo administracyjne. Część ogólna, Lublin 1994.

\section{Wprowadzenie}

Zasada efektywności działania administracji została uznana za zasadę prawa administracyjnego ${ }^{1}$. Pozostaje aktualny pogląd W. Dawidowicza: „jeżeli w administracji państwowej widzimy celową organizację powołaną do realizacji zadań państwa, jeżeli dalej uznajemy, że zadania te mają charakter publiczny, w tym sensie, że dotyczą istotnych interesów społeczeństwa, to w tych warunkach nie może być miejsca dla poglądu, że organy administracji państwowej mogą działać byle jak i że z istoty

${ }^{1}$ E. Olejniczak-Szałowska, Zasada sprawności działań administracji (zasada efektywności), w: Prawo administracyjne. Pojęcia, instytucje, zasady w teorii i orzecznictwie, pod red. M. Stahl, Warszawa 2016, s. 196. 
ich zadań nie wynika konieczność sprawnego działania" ${ }^{2}$. Zasada efektywności działania organów administracji wprowadza normatywny obowiązek sprawnego działania administracji publicznej ${ }^{3}$. Z. Kmieciak odnosi ją nie tylko do skuteczności tworzonego przez administrację prawa, ale również do skuteczności i efektywności rozstrzygnięć administracyjnych ${ }^{4}$. A. Błaś dodaje, że administracja publiczna, dążąc do zwiększania swojej efektywności, nie może zapominać o tym, że prawo było i pozostaje do dziś stałym i podstawowym, nigdy zaś drugorzędnym, punktem odniesienia dla działalności organów administracji publicznej.

Jednym z podstawowych zadań organów administracji publicznej jest czuwanie nad efektywnym wykonaniem uprawnień i obowiązków przez jednostkę. Ich źródłem są akty generalne i akty indywidualne. Jednostka uzyskuje prawo do korzystania z uprawnienia administracyjnoprawnego po jego skonkretyzowaniu w ramach postępowania administracyjnego. Organ administracji publicznej, wydając decyzję administracyjną, ingeruje w sferę prawną podmiotu znajdującego się poza aparatem państwa, w sposób władczy i jednostronny kształtuje jego prawa i obowiązki ${ }^{5}$. Wejście decyzji administracyjnej do obrotu prawnego rodzi podwójny skutek prawny: z jednej strony wiąże ona organ, który ją wydał, z drugiej rodzi uprawnienia i obowiązki o charakterze procesowym i materialnym ${ }^{6}$. Przedmiotem zainteresowania autora $-\mathrm{z}$ punktu widzenia podjętego tematu opracowania - staną się decyzje, których treścią są uprawnienia administracyjnoprawne skonkretyzowane przez organ, które początek swój biorą w przepisach prawa administracyjnego materialnego. „Materialne prawo administracyjne jest źródłem bardzo wielu różnorodnych uprawnień. Spośród około tysiąca obowiązujących obecnie w Polsce ustaw w niemal w każdej z nich możemy spotkać przepisy, które stwarzają szansę lub gwarantują jednostce możliwość uzyskania od państwa lub od innych podmiotów sprawujących w nim władzę publiczną działań zapewniających jej korzystna, podlegającą ochronie prawnej (wobec tego państwa, jego organów, a także innych podmiotów prawa), sytuację"7.

${ }^{2}$ W. Dawidowicz, Zagadnienia ustroju administracji państwowej w Polsce, Warszawa 1970 , s. 53.

${ }^{3}$ E. Olejniczak-Szałowska, op. cit., s. 196.

${ }^{4}$ Z. Kmieciak, Skuteczność regulacji administracyjnoprawnej, Łódź 1994, s. 54 i n.

${ }^{5}$ E. Śladkowska, Wydanie decyzji administracyjnej bez podstawy prawnej lub z rażacym naruszeniem prawa w ogólnym postępowaniu administracyjnym, Warszawa 2013, s. 17.

${ }^{6}$ J. Borkowski, Decyzja administracyjna, Łódź-Zielona Góra 1998, s. 99.

${ }^{7}$ D.R. Kijowski, Pojeccie, rodzaje i typy uprawnień administracyjnych, w: Prawo administracyjne materialne, seria System Prawa Administracyjnego, pod red. R. Hausera, Z. Niewiadomskiego, A. Wróbla, t. 7, Warszawa 2017, s. 250-251. 
Celem niniejszego opracowania jest odniesienie się do problematyki wykonania decyzji administracyjnej przez stronę w kontekście granic trwałości aktu administracyjnego, wskazanie instytucji prawnych wyposażających organ administracji publicznej w kompetencję do kontroli jej wykonania oraz wskazanie przypadków odpowiedzialności odszkodowawczej organów administracji publicznej w związku z pozbawieniem jednostki prawa nabytego na mocy aktu administracyjnego w aspekcie sprawności działania administracji publicznej. Powstaje również pytanie o to, czy zasada efektywności działania administracji publicznej może mieć znaczenie dla oceny procesu kontroli wykonania decyzji administracyjnej przez stronę. Podniesione zagadnienie wymaga podjęcia szczególnego trudu badawczego, gdyż niezbędna staje się analiza stosowania nie tylko przepisów prawa administracyjnego procesowego, ale również materialnego.

\section{Pojęcia uprawnienia administracyjnoprawnego i decyzji administracyjnej uprawniającej}

Analiza problematyki pozbawienia jednostki przyznanego jej uprawnienia na mocy aktu administracyjnego nie jest możliwa bez wyjaśnienia podstawowych pojęć dla nauki prawa administracyjnego, a mianowicie pojęć "uprawnienia administracyjnoprawnego" $i$ "decyzji administracyjnej uprawniającej". Ze względu na to, że w doktrynie prawa znajdziemy wiele opracowań odnoszących się do pojęcia "aktu administracyjnego", zbędne jest ich powielanie w niniejszym tekście ${ }^{8}$.

\footnotetext{
${ }^{8}$ Autor posłuży się w niniejszym artykule pojęciem "aktu administracyjnego" w rozumieniu przyjętym przez K.M. Ziemskiego, który pisze, że przez akt administracyjny należy rozumieć "czynności prawne zmierzające do wywołania określonych skutków prawnych, władcze, kierowane na zewnątrz administracji oświadczenie woli kompetentnego podmiotu wykonującego zadania z zakresu administracji publicznej, wyrażające rozstrzygnięcie co do konsekwencji prawnych, a więc konsekwencji norm indywidualnych bądź norm generalnych, dla zindywidualizowanego, tak od strony przedmiotowej, jak i podmiotowej stanu faktycznego, dotyczące indywidualnie wskazanych podmiotów, wyznaczając im zachowania w konkretnie określonych sytuacjach, w sposób bezpośredni wywołując zamierzony skutek prawny, w ten sposób załatwiając sprawę" (K.M. Ziemski, Indywidualny akt administracyjny jako forma działania administracji, Poznań 2005, s. 516). Por. też m.in.: J. Borkowski, Decyzja administracyjna, Warszawa 1970; idem, Prawo administracyjne, Warszawa 1975; idem, Zmiana i uchylenie ostatecznej decyzji administracyjnej, Warszawa 1967; W. Chróścielewski, Akt administracyjny generalny, Łódź 1994; J. Starościak, Prawne formy działania administracji, Warszawa 1957; idem, Prawo administracyjne, Warszawa 1977; E. Ura, E. Ura, Prawo administracyjne, Warszawa 1999; J. Zimmermann, Prawo
} 
Pojęcie „uprawnienia administracyjnoprawnego" nie zostało zdefiniowane przez prawodawcę na gruncie powszechnie obowiązujących przepisów prawa. Zadanie to pozostawione zostało doktrynie i judykaturze. Jest to pojęcie wyłącznie języka prawniczego. Doktryna prawa administracyjnego raczej nie posługuje się pojęciem "uprawnienia administracyjnoprawnego". Częściej odnosząc się do uprawnień nabytych na mocy aktu administracyjnego, w literaturze używa się pojęcia „publiczne prawo podmiotowe ${ }^{\prime \prime}$. W. Dawidowicz wyróżnia następujące typy uprawnień: „uprawnienie w postaci «możności prawnej» żądania stosowania normy prawa administracyjnego w celu uzyskania określonego pozwolenia (np. pozwolenia na wykonanie czynności objętej zakazem względnym) lub uprawnienia (np. uprawnienia do zajęcia cudzej nieruchomości); uprawnienie w postaci «wolności od obowiązku» (np. ustawowe zwolnienia od obowiązku ponoszenia świadczeń na różne cele); uprawnienie w postaci "prawa” stanowiącego korelat nałożonego obowiązku (np. ustawowe prawo do wynagrodzenia i odszkodowanie służące osobom obciążonym obowiązkiem świadczeń na cele publiczne); uprawnienie w postaci «sfery wolności prawnie chronionej», powstałej z wyłączeniem spod zakazu względnego"10. Klasyfikację uprawnień administracyjnoprawnych przedstawił J. Borkowski. Zalicza do nich: „po pierwsze, prawa nabyte, których treścią jest zezwolenie na podjęcie działania przez podmiot uprawniony. Aktywność podmiotu uprawnionego będzie rozpoczynała się po otrzymaniu stosownej decyzji administracyjnej. Po drugie, uprawnienie może przybrać postać stwierdzenia, że na danym podmiocie nie ciąży obowiązek. Zwolnienie $\mathrm{z}$ obowiązku może nastąpić $\mathrm{w}$ dwóch odrębnych sytuacjach: na mocy aktu administracyjnego lub władczej ingerencji organu w sytuację prawną określonego podmiotu. Do trzeciej grupy uprawnień zaliczyć możemy prawo polegające na domaganiu się świadczeń od innych podmiotów lub państwa"11. W dalszej części pracy zostanie przyjęte, że

administracyjne, Kraków 2006; M. Zimmermann, Nauka administracji i prawo administracyjne, cz. 1: Wykłady dr A.M. Zimmermanna, Poznań 1949; M. Zimmermann, M. Jaroszyński, W. Brzeziński, Polskie prawo administracyjne. Część ogólna, Warszawa 1956; K.M. Ziemski, Indywidualny akt administracyjny - jego istota, w: Prawne formy działania administracji, seria System Prawa Administracyjnego, pod red. R. Hausera, Z. Niewiadomskiego, A. Wróbla, t. 5, Warszawa 2013, s. 151-218.

${ }^{9}$ Szerzej na temat publicznych praw podmiotowych zob. W. Jakimowicz, Publiczne prawa podmiotowe, Kraków 2002.

${ }^{10}$ W. Dawidowicz, Prawo administracyjne, Warszawa 1987, s. 26-27.

${ }^{11} \mathrm{~J}$. Borkowski, Zmiana i uchylenie..., s. 17-18. 
przez uprawnienie administracyjnoprawne należy rozumieć „możliwość uzyskania lub znajdowanie się w sytuacji, w której organy administracji publicznej będą zobowiązane do podejmowania działań przysparzających korzyści jednostce" ${ }^{\prime 12}$. Krytycznie należy ocenić poczynania judykatur w zakresie ustalenia znaczenia pojęcia "uprawnienia administracyjnoprawnego", gdyż jest ono rozumiane w orzecznictwie bardzo często szeroko i w odniesieniu do przyznania kompetencji organom administracji publicznej ${ }^{13}$.

W nauce prawa administracyjnego powszechnie zaakceptowany został podział decyzji administracyjnych na uprawniające i zobowiązujące. M. Wierzbowski i A. Wiktorowska wyróżniają akty, które mogą „wprowadzać nakazy lub zakazy, nakładać obowiązki lub przyznawać uprawnienia rozmaitym podmiotom"14. Autorzy ci do aktów administracyjnych uprawniających zaliczają pozwolenia, zezwolenia, koncesje i licencj $^{15}$. W procesie stosowania prawa administracyjnego materialnego wyodrębnia się „akty nakładające obowiązki typu pieniężnego (podatki, opłaty) lub obowiązki określonego zachowania się, tj. czynienia czegoś, znoszenia lub zaniechania [...] mogą to też być akty dające uprawnienia osobiste, nieprzechodzące na inne jednostki (pozwolenie na broń), ale też i takie, które są związane z rzeczą i mogą być przenoszone na inne podmioty (przenoszenie uprawnień wynikających z pozwolenia na budowę)"16. Stosownie do skutków prawnych wywołanych przez decyzję administracyjną dzieli się je na "akty przyznające dobra lub prawa (zezwolenia, licencje, koncesje, pozwolenia); akty obciążające (nakazy, zakazy, wymierzenie opłat); akty o treści mieszanej, zawierające zarówno przyznanie czegoś, jak i pewne obciążenia oraz akty o podwójnym skutku (wydanie pozwolenia na budowę mimo sprzeciwu sąsiada)"17. J. Zimmermann, opierając się na kryterium treści aktu,

12 D.R. Kijowski, Pojęcie, rodzaje i typy uprawnień..., s. 250-251.

${ }^{13}$ Zob. wyroki Naczelnego Sądu Administracyjnego (NSA) z 20 VII 1981 r., sygn. SA 805/81, ONSA 1981, nr 2, poz. 70; wyrok NSA z 21 I 2009 r., sygn. II GSK 861/08, Legalis/el.; wyrok Wojewódzkiego Sądu Administracyjnego (WSA) w Warszawie z 24 VI 2005 r., sygn. VI SA/Wa 221/05, Legalis/el.; wyrok WSA w Warszawie z 7 IX 2005 r., sygn. IV SA/Wa 469/05, Legalis/el.; wyrok WSA w Warszawie z 8 IX 2005 r., sygn. VI SA/Wa 728/05, Legalis/el.; wyrok WSA w Krakowie z 22 I 2008 r., sygn. III SA/Kr 356/07, Legalis/el.

${ }^{14}$ M. Wierzbowski, A. Wiktorowska, Prawne formy działania administracji, w: Prawo administracyjne, pod red. M. Wierzbowskiego, Warszawa 2015, s. 256.

${ }^{15}$ Ibidem, s. 256-257.

${ }^{16}$ Z. Leoński, Prawo administracyjne, Warszawa 2008, s. 108.

17 E. Ura, E. Ura, Prawo administracyjne, Warszawa 2008, s. 108. 
rozróżnia akty administracyjne uprawniające i zobowiązujące. Autor zaznacza, że podział ten nie jest ostry ze względu na to, iż część aktów administracyjnych nakłada na swoich adresatów równocześnie obowiązki i uprawnienia, w rozmaitych proporcjach i konfiguracjach ${ }^{18}$. Albo nałożenie obowiązku jest związane z koniecznością ich realizacji w celu prawidłowego wykonania uprawnienia (zlecenie), albo przyznane uprawnienie ma łagodzić dolegliwości w związku z wykonaniem nałożonego obowiązku ${ }^{19}$. Decyzja administracyjna uprawniająca to taka, która przyznaje adresatowi aktu prawo do wykonania przyznanego - wcześniej dla niego niedostępnego - uprawnienia administracyjnoprawnego. Podstawa prawną dla takich decyzji są przepisy prawa administracyjnego materialnego ${ }^{20}$. Sa to indywidualne akty administracyjne tworzace prawo podmiotowe (uprawnienie) i/albo znoszące pewne obowiązki przewidziane $\mathrm{w}$ normach generalnych ${ }^{21}$. K. Kiczka słusznie zauważa, że "dodane za pośrednictwem decyzji uprawniających - uprawnienie i niekiedy obowiązek - nie mają charakteru bezwzględnie trwałego, bowiem mogą być następnie w drodze prawnych form działania administracji zmieniane, ograniczane, cofnięte. Normy prawa publicznego przewidują przesłanki obiektywne, np. interesy gospodarcze państwa lub przesłanki subiektywne, np. wykonywanie pozwolenia niezgodnie z ustalonymi warunkami, które stanowić mogą podstawę do ograniczenia lub cofnięcia pozwolenia"22.

\section{Wykonanie decyzji administracyjnej przez stronę}

Na wstępie powstaje pytanie, czy pojęcie wykonania jest użyteczne dla procesu oceny realizacji decyzji administracyjnej. Pojęcie wykonania i wykonalności poddaje się analizie na płaszczyźnie procesowej, materialnej oraz wypowiedzi przedstawicieli nauki prawa. W języku naturalnym

\footnotetext{
${ }^{18}$ J. Zimmermann, Prawo administracyjne, Warszawa 2016, s. 378.

${ }^{19}$ Ibidem, s. 378-379.

${ }^{20}$ M. Strzelbicki, Świadczenie usług przez podmioty wspólnotowe w Polsce - wpływ zasady traktowania narodowego i zasady kraju pochodzenia na funkcje administracji gospodarczej, w: Wspótczesne funkcje administracji gospodarczej, pod red. B. Popowskiej, Poznań 2006, s. 243.

${ }^{21}$ K. Kiczka, Administracyjnoprawne środki kształtowania sytuacji prawnej przedsiębiorców, w: Administracyjne prawo gospodarcze, A. Borkowski i in., Wrocław 2004, s. 396.

${ }^{22}$ K. Kiczka, Decyzje uprawniajace w prawie gospodarczym, w: Publiczne prawo gospodarcze, seria System Prawa Administracyjnego, pod red. R. Hausera, Z. Niewiadomskiego, A. Wróbla, t. 8B, Warszawa 2013, s. 465.
} 
przez pojęcie wykonania rozumie się „spełnienie jakiejś czynności, wprowadzenie czegoś w czyn, zrealizowanie, urzeczywistnienie"23.

Niewątpliwie, organ administracji publicznej poddaje ocenie - w granicach przewidzianych przepisami prawa administracyjnego - wykonanie decyzji administracyjnej, tj. jej realizację z punktu widzenia nie tylko zgodności z prawem, ale również z treścią decyzji administracyjnej. Ocenie poddane zostają zarówno decyzje prawidłowe, jak i dotknięte wadliwością materialnoprawną lub procesową. Istnieje subtelna, lecz wyraźna różnica w zakresie skutków prawnych wykrycia wadliwości decyzji administracyjnej przez organ a stwierdzeniem tego, że adresat aktu wykonuje go niezgodnie z jego treścią albo przepisami prawa. Wykrycie wadliwości oznacza konieczność wszczęcia trybów nadzwyczajnych postępowania administracyjnego, tj. wznowienia postępowania lub stwierdzenia nieważności decyzji administracyjnej. W przypadku gdy adresat aktu nie zastosuje się do treści decyzji administracyjnej, organ w wyniku podjętej kontroli nabywa kompetencję - po spełnieniu się przesłanek materialnych i procesowych - do wszczęcia postępowania mającego na celu wygaśnięcie, cofnięcie albo zmianę zakresu prawa nabytego na mocy aktu administracyjnego. Realizacja wspomnianej kompetencji składa się na zespół instytucji prawnych służących kontroli wykonania decyzji administracyjnej.

Wykonanie stanowi podstawowy aspekt funkcjonowania decyzji administracyjnych w obrocie prawnym ${ }^{24}$. Zapewnienie wykonania aktów administracyjnych jest ważne nie tylko dlatego, że świadczy o efektywności organów administracji publicznej, ale również ze względu na wypełnianie postulatów wynikających z zasady praworządności ${ }^{25}$. Najbardziej uniwersalne rozumienie pojęcia wykonania aktu administracyjnego, do tej pory aktualne oraz przydatne z punktu widzenia dalszych rozważań, opracował J. Jendrośka, który wykonanie aktu administracyjnego uznał za "sprowadzenie takiego stanu rzeczywistości społecznej, który jest zgodny z treścią aktu administracyjnego"26. Pojęcie „wykonania” jest analizowane przez doktrynę prawa zarówno jako pojęcie prawne, jak i prawnicze. W języku prawnym występuje ono w postaci rzeczownikowej lub przymiotnikowej w celu wyeksponowania pewnej

${ }^{23}$ E. Sobol, Nowy stownik języka polskiego, Warszawa 2002, s. 1169.

${ }^{24}$ J. Jendrośka, Zagadnienie prawne wykonania aktu administracyjnego, Wrocław 1963, s. 21.

${ }^{25}$ Z. Leoński, Egzekucja administracyjna świadczeń pieniężnych, Warszawa 1986, s. 6.

${ }^{26}$ J. Jendrośka, Zagadnienie prawne..., s. 23. 
cechy aktu administracyjnego, przesądzając o tym, że akt można określić mianem "wykonalnego" lub "niewykonalnego"27. Przepis art. $156 \S 1$ Kodeksu postępowania administracyjnego ${ }^{28}$ przesądza o tym, że podstawą stwierdzenia nieważności decyzji administracyjnej jest okoliczność, iż decyzja była niewykonalna w dniu jej wydania i jej niewykonalność ma charakter trwały. O wykonaniu decyzji administracyjnej jest mowa również $\mathrm{w}$ art. 11 k.p.a., który stanowi, że organy administracji publicznej powinny wyjaśniać stronom zasadność przesłanek, którymi kierują się przy załatwieniu sprawy, aby w ten sposób w miarę możności doprowadzić do wykonania przez strony decyzji bez potrzeby stosowania środków przymusu. Część autorów rozróżnia pojęcie "wykonania" i „wykonalności” decyzji administracyjnej. Zdaniem M. Święckiego, w odróżnieniu od "wykonania”, przez które należy rozumieć czynności strony uprawnionej lub zobowiązanej albo organu egzekucyjnego w celu spowodowania takiego stanu rzeczywistości społecznej, który jest zgodny z treścią aktu, "wykonalność" to konstrukcja teoretycznoprawna, utworzona na podstawie analizy obowiązujących przepisów, które określają zarówno przesłanki dopuszczające wykonanie decyzji nieostatecznej, jak i nierozerwalnie z tym związane warunki i sposoby wstrzymania tego wykonania ${ }^{29}$. Wykonanie i wykonalność aktu administracyjnego są wzajemnie ze sobą powiązane w ten sposób, że decyzja może być wykonana tylko wtedy, gdy jest wykonalna, sama zaś wykonalność nie przesądza jeszcze o wykonaniu, które może stanowić jej następstwo, ale nie musi ${ }^{30}$. Pojęcie „wykonania” i wykonalności” decyzji administracyjnej cieszy się dużym zainteresowaniem koryfeuszy nauki prawa administracyjnego ${ }^{31}$. Cenną uwagę natury ogólnej poczy-

\footnotetext{
27 A. Krawczyk, Wykonalność aktu i czynności organu administracji publicznej, Warszawa 2013, s. 9.

${ }^{28}$ Ustawa z dnia 14 VI 1960 r. Kodeks postępowania administracyjnego (tekst jedn. Dz.U. 2017, poz. 1257), dalej „k.p.a.”.

${ }^{29}$ M. Święcki, Wykonalność decyzji nieostatecznej wedtug kodeksu podstępowania administracyjnego, "Zeszyty Naukowe Uniwersytety Mikołaja Kopernika” 1976, Prawo XIV, z. 75 , s. 143 .

${ }^{30}$ T. Biernat, Ostateczność i prawomocność decyzji administracyjnych a ich wykonalność, „Państwo i Prawo" 1984, z. 9, s. 81-82.

${ }^{31}$ J. Jendrośka, Zagadnienie prawne..., s. 23 i n.; Z. Kmieciak, Wykonanie decyzji administracyjnej w świetle przepisów Ordynacji podatkowej, w: Instytucje procesu administracyjnego i sadowoadministracyjnego. Ksiega jubileuszowa dedykowana Prof. nadzw. dr. hab. Ludwikowi Żukowskiemu, pod red. J. Posłusznego, Z. Czarnika, R. Sawuły, Przemyśl-Rzeszów 2009, s. 29; J. Borkowski, Wstrzymanie wykonania decyzji w postępowaniu kasacyjnym, "Monitor Prawniczy" 2005, z. 14, s. 25.
} 
niła L. Klat-Wertelecka, wskazując, że „wykonalność aktu, oznaczająca możliwość i nakaz jego realizacji, jest pojęciem obowiązującym w całym systemie prawa administracyjnego, pojawiającym się zarówno w przepisach prawa procesowego, jak i materialnego, a mającym podstawowe znaczenie dla egzekucji administracyjnej"32. Decyzja administracyjna jest podstawą dla kształtowania stosunków społecznych. Nie jest celem samym w sobie. Wykonanie jest jednym z etapów posługiwania się aktem administracyjnym w obrocie prawnym ${ }^{33}$. Podobnie twierdzi T. Biernat, że „o ile ostateczność i prawomocność decyzji, jako cechy decyzji związane z zasadą stabilności, służąc zabezpieczeniu porządku prawnego, tworzą nowy stan prawny, o tyle wykonalność i wymagalność decyzji wiążą się z możliwością jej realizacji i stworzenia nowego stanu faktycznego"34. T. Biernat odróżnił pojęcie wykonania i wykonalności, wskazując, że wykonalność aktu administracyjnego jest to stan, w którym decyzja nadaje się do wykonania, a równocześnie może i powinna być wykonana" ${ }^{\prime 3}$. Autor ten stwierdza, że pojęcie wykonania decyzji należy łączyć nie tylko z aktami administracyjnymi uprawniającymi, ale również z zawierającymi w swojej treści zarówno uprawnienie, jak i obowiązek ${ }^{36}$. Dostrzega on konieczność rozgraniczenia wykonalności $\mathrm{w}$ znaczeniu formalnym i materialnym, wskazując na rozmaite przyczyny takiego stanu ${ }^{37}$. Jedną z nich jest, zdaniem T. Biernata, wyrażona w art. $162 \S 1$ pkt 1 k.p.a. przesłanka prowadząca do stwierdzenia wygaśnięcia decyzji administracyjnej, która stała się bezprzedmiotowa ${ }^{38}$. Przed stwierdzeniem wygaśnięcia decyzji zachowuje ona formalnie wykonalność, lecz faktycznie nie może być zrealizowana. Autor ten łączy uzyskanie przez akt administracyjny przymiotu wykonalności w znaczeniu formalnym z chwila, po pierwsze, uzyskania przez decyzję administracyjną cechy ostateczności, po drugie, nadania lub zaopatrzenia decyzji nieostatecznej w rygor natychmiastowej wykonalności oraz złożenia przez strony oświadczenia, że podjęta nieostateczna decyzja jest zgodna ze zgłoszonymi żądaniami ${ }^{39}$.

${ }^{32}$ L. Klat-Wertelecka, Niewykonalność obowiazku administracyjnoprawnego, „Wrocławsko-Lwowskie Zeszyty Prawnicze" 2012, nr 3, s. 278.

${ }^{33}$ J. Jendrośka, Zagadnienie prawne..., s. 21.

${ }^{34}$ T. Biernat, op. cit., s. 81.

${ }^{35}$ Ibidem, s. 82.

${ }^{36}$ Ibidem.

${ }^{37}$ Ibidem.

${ }^{38}$ Ibidem.

${ }^{39}$ Ibidem. 
Problem wykonania i wykonalności decyzji administracyjnej został poruszony również przez M. Święckiego, który rozróżnił te dwa pojęcia. Przez wykonanie rozumiał on czynności strony uprawnionej, zobowiązanej lub organu egzekucyjnego, które mają swoje odzwierciedlenie w przepisach prawa powszechnie obowiązującego i mają na celu spowodowanie takiego stanu w rzeczywistości społecznej, który zgodny jest z treścią aktu ${ }^{40}$. Zdaniem tego autora wykonalność jest konstrukcją teoretycznoprawną stworzoną na podstawie przepisów prawa, które wskazują na przesłanki nie tylko wykonania decyzji nieostatecznej, ale również wstrzymania tego wykonania ${ }^{41}$. Stosunek między wykonaniem i wykonalnością jest uwarunkowany, co oznacza, że wykonalność warunkuje wykonanie ${ }^{42}$. W swoich rozważaniach M. Święcki wskazał, że pojęcie wykonalności decyzji administracyjnej ma znaczenie metodologiczne, stanowi bowiem narzędzie badawcze przydatne do lepszego poznania zasad i związków między normami prawa administracyjnego ${ }^{43}$.

Z kolei zdaniem T. Wosia „przedmiotem wykonania decyzji administracyjnej jest każde zachowanie podmiotu uprawnionego lub zobowiązanego do jej wykonania (adresata decyzji) polegające na działaniu, zaniechaniu określonego działania, znoszeniu zachowań innych podmiotów, a nawet świadczeniu w rozumieniu prawa cywilnego (np. sumy pieniężnej odszkodowania za wywłaszczoną nieruchomość). Decyzja administracyjna zostaje wykonana, gdy rzeczywisty stan stosunków społecznych odpowiadać będzie stanowi określonemu w niej jako powinny" ${ }^{\prime 4}$. Autor ten dodaje, że „w rzeczywistości problem wykonania decyzji administracyjnych dotyczy aktów zobowiązujących, ustalających dla ich adresatów nakazy powinnego zachowania lub zakazy określonego zachowania, decyzji, na podstawie których określony podmiot uzyskuje uprawnienie i mocą których zostają na niego nałożone określone obowiązki (np. decyzja o wywłaszczeniu nadająca wywłaszczającemu określone prawa rzeczowe), oraz decyzji, na podstawie których jeden podmiot jest do czegoś zobowiązany, a drugi wyłącznie uprawniony" ${ }^{\prime \prime 5}$.

${ }^{40}$ M. Święcki, Wykonalność decyzji nieostatecznej..., s. 143-160.

${ }^{41}$ Ibidem, s. 143.

${ }^{42}$ Ibidem, s. 143-160.

${ }^{43}$ Ibidem, s. 160.

${ }^{44}$ T. Woś, Wykonalność decyzji administracyjnej, w: Postępowanie administracyjne, pod red. T. Wosia, Warszawa 2017, s. 418. Por. również J. Zimmermann, Prawo administracyjne, Warszawa 2017, s. 409 i n.

${ }^{45}$ Szerzej zob. T. Woś, Wykonalność..., s. 348. 
Podsumowując, należy wskazać, że organ administracji publicznej kontroluje wykonanie decyzji administracyjnej. Organ ocenia, czy jednostka sprowadziła taki stan rzeczywistości społecznej, który jest zgodny z treścią aktu administracyjnego, a dodatkowo zgodny z przepisami prawa powszechnie obowiązującego. Należy zgodzić się z tezą postawioną przez J. Jendrośkę, że problematyki wykonania decyzji administracyjnej nie można ograniczać do jej przymusowej realizacji ${ }^{46}$. Jednostka wykonuje decyzję administracyjną wtedy, gdy realizuje ona zarówno obowiązek publicznoprawny, jak i uprawnienie administracyjnoprawne ${ }^{47}$.

\section{Instrumenty kontroli wykonania decyzji administracyjnej a jej trwałość}

Prawo administracyjne procesowe przyjmuje ogólną zasadę trwałości rozstrzygnięć organów administracji publicznej, która daje możliwość ingerencji w moc obowiązującą decyzji administracyjnej nie tylko na podstawie przepisów k.p.a., ale również przepisów szczególnych ${ }^{48}$. Trwałość decyzji administracyjnej to kategoria materialnego prawa administracyjnego ${ }^{49}$, regulowana zarówno przepisami prawa materialnego, jak i procesowego ${ }^{50}$. Zasada trwałości ostatecznych decyzji administracyjnych została unormowana w art. 16 k.p.a., który stanowi, że decyzje, od których nie służy odwołanie w administracyjnym toku instancji lub wniosek o ponowne rozpatrzenie sprawy, są ostateczne. Uchylenie

${ }^{46}$ J. Jendrośka, Zagadnienie prawne..., s. 21.

${ }^{47}$ Szerzej na temat wykonania decyzji administracyjnej zob. W. Trybka, Wykonanie decyzji administracyjnej w prawie polskim, niemieckim i austriackim, w: Nowe wyzwania i rozwiazania w polskim systemie praw człowieka, pod red. J. Jaskierni, K. Spryszaka, Toruń 2018, s. 470-487; idem, Ocena wykonania decyzji administracyjnej, „Zeszyty Naukowe Państwowej Wyższej Szkoły Zawodowej im. Witelona w Legnicy" 2018, nr 27(2), s. 117-131.

${ }^{48}$ B. Adamiak, Granice ochrony praw nabytych w prawie procesowym administracyjnym a kontrola ich wykonania, w: Prawo procesowe administracyjne, seria System Prawa Administracyjnego, pod red. R. Hausera, Z. Niewiadomskiego, A. Wróbla, t. 9, Warszawa 2017, s. 323 .

${ }^{49}$ J. Filipek, Normy prawa materialnego a normy postępowania, w: Administracja publiczna w państwie prawa. Ksiega jubileuszowa dla Profesora Jana Jendrośki, pod red. B. Adamiak, Wrocław 1999, s. 100.

${ }^{50}$ J. Jendrośka, Ogólne postępowanie administracyjne i sadowoadministracyjne, Wrocław 2007, s. 111. 
lub zmiana takich decyzji, stwierdzenie ich nieważności oraz wznowienie postępowania może nastąpić tylko w przypadkach przewidzianych w kodeksie lub ustawach szczególnych (§ 1). Decyzje mogą być zaskarżane do sądu administracyjnego z powodu ich niezgodności z prawem, na zasadach i w trybie określonych w odrębnych ustawach (§ 2). Decyzje ostateczne, których nie można zaskarżyć do sądu, są prawomocne (§ 3). „Zasada ogólna trwałości decyzji ostatecznych ma podstawowe znaczenie dla stabilizacji opartych na decyzji skutków prawnych, dlatego w świadomości społecznej zasada ta uchodzić będzie z pewnością za jedno z kardynalnych założeń całego systemu ogólnego postępowania administracyjnego. [...] Formalna strona zasady ogólnej trwałości decyzji ostatecznej wyraża się w tym, że decyzje te obowiązują tak długo, dopóki nie zostaną uchylone lub zmienione przez nową decyzję opartą na odpowiednim przepisie prawnym. Jest to tzw. domniemanie mocy obowiązującej decyzji. Wydanie nowej decyzji jest więc jedynym sposobem całkowitego lub częściowego pozbawienia decyzji ostatecznej jej mocy obowiązującej" ${ }^{\prime 1}$. Decyzji ostatecznej służy tzw. domniemanie legalności, które oznacza, że jest ona ważna i powinna być wykonywana dopóty, dopóki nie zostanie zmieniona, uchylona lub nie zostanie stwierdzona jej nieważność przez właściwy organ i z zachowaniem przepisanego trybu postępowania ${ }^{52}$. Od zasady trwałości decyzji administracyjnej istnieją wyjątki. Do wspomnianych wyjątków zaliczamy instytucje prawne wyposażające organ administracji publicznej w kompetencje do oceny realizacji decyzji administracyjnej, a mianowicie: stwierdzenie wygaśnięcia decyzji administracyjnej (art. 162 k.p.a.) oraz instytucję materialnoprawną cofnięcia uprawnienia (art. 163 k.p.a.) - z tym jednak, że stanowią one grupę wyjątków odrębną od trybów nadzwyczajnych postępowania administracyjnego. Przedmiotem nadzwyczajnych trybów postępowania administracyjnego jest wyeliminowanie z obrotu prawnego wadliwych decyzji, przedmiotem regulacji szczególnej jest natomiast kontrola prawidłowości wykonania decyzji administracyjnej ${ }^{53}$.

${ }^{51}$ W. Dawidowicz, Ogólne postępowanie administracyjne. Zarys systemu, Warszawa 1962, s. 123.

${ }^{52}$ B. Adamiak, Komentarz do art. 16, w: B. Adamiak, J. Borkowski, Kodeks postępowania administracyjnego. Komentarz, Warszawa 2017, s. 456. Por. też wyrok NSA z 6 II 1992 r., sygn. SA/Po 1203/91, ONSA 1992, nr 3-4, poz. 78.

${ }^{53}$ B. Adamiak, J. Borkowski, Postępowanie administracyjne i sądowoadministracyjne, Warszawa 2017, s. 421 i n. 


\section{Odpowiedzialność odszkodowawcza organu administracji publicznej za pozbawienie jednostki prawa nabytego na mocy aktu administracyjnego}

W pierwszej kolejności należy ustalić, jak rozumieć pojęcie „odpowiedzialności odszkodowawczej, a następnie dopiero wskazać przypadki, gdy organ administracji publicznej ponosi odpowiedzialność odszkodowawczą za pozbawienie uprawnienia. Odpowiedzialność w języku naturalnym to „konieczność, obowiązek moralny lub prawny odpowiadania za swoje czyny i ponoszenia za nie konsekwencji" ${ }^{\prime 54}$. Pojęcie "odpowiedzialność" zostało stworzone przez prawo. W prawie rzymskim używano takich określeń, jak: respondere, responsio, responsum, które otrzymały $w$ prawie średniowiecznym swe odpowiedniki niemal we wszystkich językach europejskich ${ }^{55}$. Zdaniem W. Langa "odpowiedzialność w najszerszym znaczeniu zarówno na gruncie przepisów prawa, jak i nauki prawa znaczy we wszystkich dyscyplinach prawniczych zasadę ponoszenia przez podmioty przewidzianych prawem ujemnych konsekwencji za zdarzenia lub stany rzeczy podlegające ujemnej kwalifikacji normatywnej i przypisywalne prawnie określonemu podmiotowi w danym porządku prawnym"56. Odpowiedzialność jest ponoszeniem określonych konsekwencji przez jednostki lub zbiorowości w następstwie przekroczenia lub niewypełnienia kompetencji albo niewykonania lub wadliwego wykonania obowiązków ${ }^{57}$. Trudno nie zgodzić się z M. Górskim, który pisze, że „odpowiedzialność prawna to taka odpowiedzialność, która jest oparta na normach prawnych - norma prawa określa obowiązek i sposób rozliczenia z jego wykonania" ${ }^{\prime 5}$. Zdaniem W. Radeckiego na definicję odpowiedzialności prawnej składają się dwa elementy ujemne: w postaci negatywnej oceny normatywnej określonego zdarzenia lub stanu rzeczy oraz negatywnych konsekwencji owego

${ }^{54}$ S. Skorupka, H. Auderska, Z. Łempicka, Mały słownik języka polskiego, Warszawa 1968 , s. 490.

${ }^{55}$ J. Filek, Ontologizacja odpowiedzialności, Kraków 1996, s. 18.

${ }^{56}$ W. Lang, Struktura odpowiedzialności prawnej. Studium analityczne z dziedziny teorii prawa, "Zeszyty Naukowe Uniwersytetu Mikołaja Kopernika w Toruniu” 1968, z. 8, s. 31.

${ }^{57}$ W. Warkałło, Odpowiedzialność odszkodowawcza. Funkcje, rodzaje, granice, Warszawa 1972 , s. 36.

${ }^{58}$ M. Górski, Odpowiedzialność administracyjnoprawna w ochronie środowiska. Odpowiedzialność za szkody w środowisku i inne instrumenty odpowiedzialności administracyjnoprawnej, Warszawa 2007, s. 10. 
zdarzenia lub stanu rzeczy ${ }^{59}$. W ramach odpowiedzialności pojawia się obowiązek pierwotny, który zostaje naruszony, i obowiązek wtórny odpowiedzialność - oznaczający ponoszenie sankcji za naruszenie obowiązku pierwotnego ${ }^{60}$.

Akty normatywne rangi ustawy regulują sytuacje prawne, w których organ administracji publicznej jest obowiązany do naprawienia szkody w związku z pozbawieniem jednostki prawa nabytego na mocy aktu administracyjnego ${ }^{61}$. W tym przypadku odszkodowanie należy się adresatowi aktu administracyjnego z tytułu szkód poniesionych wskutek pozbawienia uprawnień ustalonych ostateczną decyzją administracyjną ${ }^{62}$. Pozbawienie jednostki uprawnienia przez organ administracji publicznej za odszkodowaniem w doktrynie prawa określane jest mianem "wywłaszczenia prawa"63. Przesłanki unormowane w przepisach prawa administracyjnego materialnego warunkujące cofnięcie uprawnienia administracyjnoprawnego można podzielić na dwie grupy: te, które umożliwiają uzyskanie odszkodowania, i te, po których wystąpieniu nie ma takiej możliwości. Pozostała część przepisów prawa administracyjnego materialnego w ogóle nie stanowi natomiast o odszkodowaniu w przypadku cofnięcia lub ograniczenia uprawnienia. Rację ma J. Parchomiuk, twierdząc, że "uchylenie decyzji, a co za tym idzie cofnięcie uprawnienia, może być wynikiem różnych okoliczności - tak zależnych od podmiotu uprawnionego (np. naruszenie warunków prowadzenia działalności objętej decyzją), jak i obiektywnych (zmiana okoliczności prawnych i faktycznych powodująca dezaktualizację stanu prawnego ukształtowanego decyzją). Roszczenie odszkodowawcze wchodzi w grę tylko w tym drugim przypadku, w pierwszej bowiem sytuacji cofnięcie uprawnień jest rodzajem sankcji z tytułu naruszenia przepisów regulujących działalność prowadzoną na podstawie decyzji" ${ }^{\prime \prime 4}$.

${ }^{59}$ W. Radecki, Odpowiedzialność administracyjna w ochronie środowiska. Geneza, rozwój, perspektywy, Warszawa 2010, s. 399-400.

${ }^{60}$ Ibidem, s. 60. s. 46 .

${ }^{61}$ J. Boć, Wyrównanie strat wynikłych z legalnych działań administracji, Wrocław 1971,

${ }^{62} \mathrm{~J}$. Parchomiuk, Przesłanki odpowiedzialności za działania legalne administracji, w: Odpowiedzialność odszkodowawcza administracji, seria System Prawa Administracyjnego, pod red. R. Hausera, Z. Niewiadomskiego, A. Wróbla, t. 12, Warszawa 2016, s. 531.

${ }^{63}$ Por. M. Jaroszyński, M. Zimmermann, W. Brzeziński, Polskie prawo administracyjne..., s. 346.

${ }^{64}$ J. Parchomiuk, op. cit., s. 531. 


\section{Zasada efektywności działania w obszarze prawa administracyjnego $w$ poglądach nauki prawa}

Efektywność obok praworządności powinna być traktowana jako cecha, która wpisana została na stałe w działalność organów administracji publicznej. Inaczej na efektywność działań administracji publicznej patrzy nauka administracji i prawo administracyjne. Nauka administracji traktuje sprawność jako fragment otaczającej nas rzeczywistości. Z kolei prawo administracyjne szuka jej podstaw w obowiązującym porządku normatywnym. „Pojęcie sprawności działania administracji publicznej jest pojęciem-narzędziem, a także pojęciem-przedmiotem badań nauki indukcyjnej. Pojęcie sprawności, efektywności prawa jest pojęciem-narzędziem, a także pojęciem-przedmiotem badań nauki dedukcyjnej. Mimo różnic w metodologii omawianych nauk, z jakimi związane są te dwa różne pojęcia, trzeba zaznaczyć, że istnieje między nimi związek funkcjonalny. Jedno z założeń metodologicznych nauki prawa administracyjnego podnosi, że nie można mówić o skuteczności systemu prawnego bez zbadania, czy system realizuje w praktyce cele i zadania, którymi kierował się jego twórca. W nauce prawa administracyjnego podkreśla się, że badaniom podlega przede wszystkim sprawność, efektywność obowiązującego i stosowanego systemu prawnego"65.

Nauka prawa najczęściej poszukuje źródeł normatywnego wyrazu realizacji zasady efektywnego działania administracji w przepisach prawa administracyjnego materialnego, nie analizując omawianej zasady przez pryzmat etapów stosowania prawa procesowego, w tym współstosowania norm procesowych i materialnych. Nauka prawa zasadę efektywności umieszcza wśród zasad działania administracji publicznej.

Najbardziej wąskie rozumienie zasady efektywności w nauce prawa zaprezentował J. Starościak, który łączył efektywne działania administracji z odpowiednim doborem metod i form jej działania. Autor ten wskazał, że efektywność działania organów państwa można ocenić na podstawie: programu ich działania, organizacji, przygotowania kadry oraz umiejętności posługiwania się społecznie akceptowanymi metoda$\mathrm{mi}^{66}$. Efektywność administracji należy ocenić przez porównanie przyję-

${ }^{65}$ I. Skrzydło-Niżnik, Pojęcia i kryteria sprawności działania administracji publicznej w nauce prawa administracyjnego i w nauce administracji, w: Prawo do dobrej administracji. Materiały ze Zjazdu Katedr Prawa i Postępowania Administracyjnego. Warszawa-Dębe 23-25 września 2002 r., pod red. Ł. Złakowskiego, Warszawa 2003, s. 231.

${ }^{66}$ J. Starościak, Problemy współczesnej administracji, Warszawa 1972, s. 25 i n. 
tych wstępnych założeń w zakresie wykonanego zadania z osiągniętym celem $^{67}$. Za podstawowe kryterium skuteczności uznaje się również racjonalność działania organów ${ }^{68}$. Z. Kmieciak w swojej monografii Skuteczność regulacji administracyjnoprawnej szczególnie eksponuje występujące w praktyce trudności w ustaleniu związków przyczynowych między określonymi normami a różnymi działaniami w płaszczyźnie oceny ich efektywności ${ }^{69}$. Badając skuteczność prawa, wyróżnić można różne rodzaje skuteczności. Ze względu na podział celów norm prawnych skuteczność dzieli się na: behawioralną, psychologiczna, finistyczną i społeczno-wychowawczą ${ }^{70}$. E. Ura dostrzega szerszy kontekst zasady efektywności, uznając, że skuteczne działanie organów administracji publicznej to takie, które w pełni zaspokaja oczekiwania społeczne. Realizacja tej zasady zależy od wielu czynników: politycznych, gospodarczych, organizacyjno-technicznych, a także prawnych. Każde rozstrzygnięcie podejmowane przez organy administracji publicznej stanowi wyraz podjętego przez nie wyboru, na który wpływ ma wiele czynników, spośród których ogromne znaczenie mają elementy pozaprawne $^{71}$. Zdaniem E. Olejniczak-Szałowskiej zasada efektywności znajduje oparcie w szczególności, po pierwsze, „w przepisach o nadzorze nad samorządem terytorialnym dotyczących zawieszenia organów samorządowych i ustanowienia zarządu komisarycznego, po drugie, w przepisach o nadzorze nad działalnością wojewody, po trzecie, w przepisach nakazujących wojewodzie, jako zwierzchnikowi zespolonej administracji rządowej, zapewnić warunki do skutecznego działania tej administracji, a także $\mathrm{w}$ przepisach upoważniających wojewodę do tworzenia delegatur urzędu wojewódzkiego, po czwarte, w przepisach nakazujących przeprowadzenie czynności kontrolnych, oraz w przepisach zobowiązujących kierownika podmiotu kontrolowanego do zapewnienia kontrolerowi warunków niezbędnych do sprawnego przeprowadzenia kontroli"72.

${ }^{67}$ J. Kurnal, Zarys teorii organizacji działania i zarządzania, Warszawa 1970, s. 223.

${ }^{68}$ Szerzej na ten temat zob. J. Łukasiewicz, Prawne uwarunkowania skuteczności działania administracji państwowej, Lublin 1999.

${ }^{69}$ Szerzej na temat efektywności prawa badanej w kontekście zjawisk występujących w otaczającej nas rzeczywistości zob. Z. Kmieciak, Skuteczność regulacji.., s. 14 i n.

${ }^{70}$ Szerzej na temat rodzajów skuteczności prawa zob. I. Skrzydło-Niżnik, Pojęcia i kryteria..., s. 234 i n.

${ }^{71}$ E. Ura, Prawo administracyjne, Warszawa 2015, s. 103.

${ }^{72}$ E. Olejniczak-Szałowska, op. cit., s. 196. 


\section{Podsumowanie}

Grupę instrumentów prawnych wyposażających organ administracji publicznej w kompetencję do oceny realizacji decyzji administracyjnej de facto tworzą dwa rodzaje postępowań, a mianowicie: postępowanie w przedmiocie stwierdzenia wygaśnięcia decyzji administracyjnej (art. 162 k.p.a.) oraz postępowanie w przedmiocie cofnięcia lub zmiany zakresu przyznanego uprawnienia na podstawie przepisów szczególnych (art. 163 k.p.a.). Ich celem nie jest weryfikacja aktu administracyjnego. Pojęcie „weryfikacji” decyzji administracyjnej odnosić należy jedynie do trybów nadzwyczajnych postępowania administracyjnego. Adresat aktu ma prawo sam decydować o tym, czy wykona akt administracji oraz w jaki sposób to zrobi, nie oznacza to jednak, że ma on pełną dowolność. Wykonanie decyzji administracyjnej zawsze powinno mieć miejsce na podstawie jej treści i musi być zgodne z przepisami prawa powszechnie obowiązującego, w innym wypadku jednostka naraża się na utratę uprawnienia. Natomiast strona, która rozporządza prawem nabytym, nie może zostać przymuszona $\mathrm{w}$ trybie postępowania egzekucyjnego do jego wykonania. Nie oznacza to jednak wyłączenia w tym zakresie władztwa organów administracji publicznej ${ }^{73}$. Prawodawca ustanawia normatywny obowiązek ochrony praw nabytych na mocy aktu administracyjnego, lecz ochrona ta nie jest absolutna ${ }^{74}$. Wygaśnięcie decyzji administracyjnej lub cofnięcie nabytego na mocy aktu administracyjnego uprawnienia administracyjnoprawnego jest uzależnione od zaistnienia przesłanek procesowych i materialnych wskazanych w przepisach prawa administracyjnego ${ }^{75}$. Podstawą kontroli przeprowadzanej przez

${ }^{73}$ Szerzej na temat władztwa organów administracji publicznej w płaszczyźnie realizacji norm prawa administracyjnego procesowego zob. W. Trybka, Koncepcja władztwa procesowego, "Zeszyty Naukowe Sądownictwa Administracyjnego" 2017, nr 1, s. 65-75.

${ }^{74}$ Szerzej na temat granic władczej ingerencji organu administracji publicznej w wykonanie uprawnienia administracyjnoprawnego zob. W. Trybka, Koncepcja uzasadnienia obowiazywania zasady ochrony praw nabytych w Konstytucji RP $i$ Kodeksie postępowania administracyjnego, w: Aktualne problemy konstytucji. Ksiega jubileuszowa z okazji 40-lecia pracy naukowej profesora Bogustawa Banaszaka, pod red. H. Babiuch, P. Kapusty, J. Michalskiej, Legnica 2017, s. 992-1005.

${ }^{75}$ Szerzej na temat instytucji prawnych wygaśnięcia decyzji administracyjnego i materialnoprawnego cofnięcia uprawnienia zob. m.in.: T. Woś, Stwierdzenie wygaśnięcia decyzji administracyjnej jako bezprzedmiotowej (art. 162 k.p.a.), "Państwo i Prawo” 1992, z. 7; idem, Moc wiążąca aktów administracyjnych w czasie, Warszawa 1978; J. Borkowski, Zmiana i uchylenie..., s. 10; M. Kamiński, Materialnoprawne wygaśnięcie i proceduralne stwierdzenie wygaśnięcia mocy obowiazujacej decyzji administracyjnej, w: Kodyfikacja postępowania 
organ jest sposób wykonania uprawnienia administracyjnoprawnego. W tym miejscu należy przypomnieć, że pojęcie "uprawnienia administracyjnoprawnego" nie jest rozumiane jednolicie ani w literaturze, ani w orzecznictwie sądów administracyjnych. Rozumienie terminu „uprawnienie administracyjnoprawne" jest ściśle uzależnione od tego, do jakich instytucji prawnych lub przepisów prawnych je odnosimy. Inaczej jest ono rozumiane w płaszczyźnie analizy wyposażenia organu w kompetencje, a inaczej w obszarze oceny realizacji decyzji administracyjnej. Odmienny kształt przyjmuje uprawnienie płynące z przepisów prawa administracyjnego materialnego i procesowego.

Bez wątpienia, przywołane poglądy przedstawicieli nauki prawa odnoszące się do sposobów rozumienia zasady efektywności w obszarze prawa administracyjnego zasługują na pełną aprobatę. Natomiast dociekliwy badacz zawsze analizuje zjawiska występujące w otaczającej nas rzeczywistości prawnej wielopłaszczyznowo. Na zasadę efektywności działania można spojrzeć szerzej. Chodzi tutaj nie tylko o efektywność wewnętrzna, $\mathrm{tj}$. sprawne realizowanie przyjętej polityki działania administracji, ani nie o efektywność zewnętrzna, czyli skuteczne wykonanie zadań administracji publicznej. Zasadę efektywności działania można analizować przez pryzmat postępowania, którego przedmiotem jest ocena wykonania decyzji administracyjnej. Skuteczność działania organów administracji publicznej nie stanowi wyłącznie problemu materialnoprawnego. Odnajduje ona swoje przełożenie w płaszczyźnie procesowej. Kontrola wykonania decyzji na podstawie przepisów k.p.a. wpisuje się w ujęcie behawioralne. Zdaniem I. Skrzydło-Niżnik "skuteczność behawioralna dzieli się na materialną i procesową. Materialna występuje w sytuacji, gdy norma prawna określa, jak adresat powinien się zachować niezależnie od celów, które sobie wyznacza, proceduralna zaś dotyczy tych sytuacji, w których normy prawne wskazuja, jak powinien zachować się adresat, jeżeli chce osiągnąć pewien cel, lecz jednocześnie nie nakazują ani też nie zakazują jego realizacji"76. Decyzja administracyjna, która kończy proces stosowania przepisów prawa administracyjnego, w swojej treści oddaje to, jak adresat winien się zachować, tzn. jak, opierając się na samym rozstrzygnięciu i przepisach prawa, obowiązany jest wprowadzić w otaczającą go rzeczywistość przyznane uprawnienie administracyjnoprawne lub nałożony na niego

administracyjnego. Na 50-lecie K.P.A., pod red. J. Niczyporuka, Lublin 2010; T. Woś, Termin, warunek i zlecenie w prawie administracyjnym, „Państwo i Prawo” 1994, z. 6.

${ }^{76}$ I. Skrzydło-Niżnik, Pojęcia i kryteria..., s. 234. 
obowiązek. W badanej płaszczyźnie efektywność działania organów administracji publicznej przejawia się w dbaniu o to, żeby adresat decyzji administracyjnej wykonywał ją nie tylko zgodnie z jej treścią, ale i z przepisami prawa powszechnie obowiązującego. W przypadku gdy organ stwierdzi, że decyzja jest wykonywana niezgodnie z jej treścia, przepisami prawa lub nie jest realizowana, ma on obowiązek, korzystając z przyznanego mu władztwa administracyjnego, zaingerować w sytuację administracyjnoprawną adresata aktu administracyjnego.

\section{DEPRIVATION OF RIGHTS RESULTING FROM THE ADMINISTRATIVE DECISION AND IMPLEMENTATION OF THE PRINCIPLE OF ADMINISTRATIVE EFFICIENCY}

\section{Sum mary}

Deprivation of an entity of acquired rights deriving from an administrative act is possible through the combined application of administrative provisions of substantive and procedural law. The limits of durability acquired under an administrative decision rights are the constitutional principle of the protection of acquired rights and the general principles of administrative procedure. The permanence of the right acquired by the administrative decision is not absolute. Repeal or change of the administrative decision is possible only in the mode provided in the law, since the administrative decision makes use of the presumption of regularity.

The deprivation of administrative and legal powers in the area of public law takes place in the context of an assessment of the implementation of an administrative decision carried out by a state body. This assessment is possible with the use of two procedural institutions for the expiry of an administrative decision and a substantive institution for the withdrawal of rights. The body assesses whether the addressee of an administrative act has implemented the administrative decision not only in accordance with its content but also the provisions of the generally applicable law. The deprivation of a party of an acquired right is often accompanied by the need to award damages (grant compensation). The procedure and premises for claiming compensation liability have been regulated in the provisions of substantive administrative law.

The principle of the effectiveness of public administration bodies is one of the basic principles of administrative law. Its application is not limited only to the creation of law, but also includes the application of law by public administration bodies. The problem of the efficiency of operations of state bodies is of particular importance not only in the area of enforceability of an administrative decision, but also its authorising function. The efficiency of operations of entities in the State structure is assessed through the prism of the implementation of a given administrative decision.

Keywords: administrative decision - control - responsibility - compensation public administration authority 